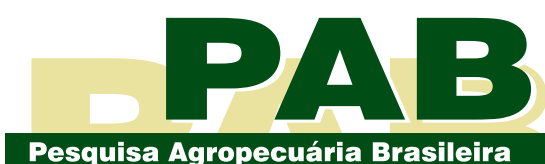

ISSN 1678-3921

Journal homepage: www.embrapa.br/pab

For manuscript submission and journal contents, access: www.scielo.br/pab

\section{Corn genotypes and crop seasons on the rate of putative haploids with the expression of gene R1-navajo}

\begin{abstract}
The objective of this work was to evaluate the influences of the factors corn (Zea mays) genotypes, crop seasons, endosperm texture, genetic background, and genetic basis on putative haploid rates (PHRs) according to the expression of gene R1-navajo (R1-nj). Forty-one corn genotypes were evaluated as pollen receptors, in crosses with the Krasnodar haploid inducer, in two crops (summer and winter), in the municipality of Maringá, in the state of Paraná, Brazil. The experimental design was completely randomized with ten replicates (ears). The response variable analyzed was the PHR, determined by the proportion of putative haploids, obtained through the $R 1-n j$ marker, in relation to the number of diploid seeds in each ear. Subsequently, generalized linear models were used to choose the one best fit to explain the PHR in function of the tested factors. Crop seasons, genotypes, and the crop seasons $\mathrm{x}$ genotypes interaction affected significantly the PHR, showing the dependence of these factors on the expression of the phenotypic marker based on anthocyanin pigmentation and determined by gene $R I-n j$. The number of clusters formed by the genotypes was different in each crop season. Ten genotypes showed higher rates in summer than in winter. Endosperm texture, genetic basis, and genetic background did not affect the PHR.
\end{abstract}

Index terms: Zea mays, haploid induction, induction rate.

\section{Genótipos de milho e safras nas taxas de haploides putativos com expressão do gene R1-navajo}

Resumo - O objetivo deste trabalho foi avaliar as influências dos fatores genótipos de milho (Zea mays), safras agrícolas, texturas dos endospermas, fundo genético e bases genéticas nas taxas de haploides putativos (THPs), conforme a expressão do gene R1-navajo (R1-nj). Foram avaliados 41 genótipos de milho como receptores de pólen, em cruzamentos com o indutor "Krasnodar haploid inducer", em duas safras (verão e inverno), no município de Maringá, no estado do Paraná, Brasil. O delineamento experimental foi o inteiramente casualizado com dez repetições (espigas). A variável resposta analisada foi a THP determinada pela proporção de haploides putativos, obtidos com base no marcador $R 1-n j$, em relação ao número de sementes diploides por espiga. Posteriormente, foram utilizados modelos lineares generalizados para escolher o mais adequado para explicar a THP em função dos fatores testados. As safras, os genótipos e a interação safras x genótipos afetaram significativamente a THP, o que evidencia a dependência destes fatores na expressão do marcador fenotípico baseado na pigmentação por antocianina e determinado pelo gene dominante $R 1-n j$. O número de 
agrupamentos formados pelos genótipos foram diferentes em cada safra. Dez genótipos apresentaram taxas maiores no verão do que no inverno. As texturas dos endospermas, as bases genéticas e o fundo genético não interferiram na THP.

Termos para indexação: Zea mays, indução de haploidia, taxa de indução.

\section{Introduction}

The selection of haploids for chromosome duplication is an essential stage for the production of doubled haploid lines in corn (Zea mays L.) (Couto et al., 2015; Ribeiro et al., 2018). According to the potential of the inducer, the rate of true haploids produced by the source genotype, also known as the haploid induction rate (Battistelli et al., 2013), can range from 2 to $15 \%$ in relation to the total of seeds (Chaikam et al., 2019).

After the stage of induction crosses, many breeding programs have adopted the phenotypic marker resulting from the expression of the R1-najavo (R1-nj) gene as a criterion to sort haploid seeds (Geiger \& Gordilho, 2009). The RI-nj gene, present in most haploid-inducing genotypes, is dominant and promotes anthocyanin pigmentation in the endosperm and in the embryo of diploid (2n) seeds from crosses with source genotypes (Nanda \& Chase, 1966). However, when gynogenetic haploids (n) are generated, the purple pigmentation is only expected in the triploid endosperm and not in the embryo, which only carries the chromosomes of the mother that does not contain this gene (Nanda \& Chase, 1966).

Besides Rl-nj, other complementary genes are required to promote anthocyanin pigmentation in seeds, especially in tropical corn germplasms, where they are not always present (Chaikam et al., 2015). Therefore, the Navajo phenotype can be completely suppressed or weakly expressed, depending on the source germplasm and environmental conditions, making the identification of haploids through this marker ineffective (Chaikam et al., 2015). In addition, the purple phenotype of the seeds may be influenced by the $C 1-I, C 2-I^{d f}$, and $I^{n I}-I D$ dominant genes, which inhibit anthocyanin synthesis (Coe, 1994; Eder \& Chalyk, 2002). There are also reports on the influence of endosperm texture on the expression of the Rl-nj marker, which may be one of the possible explanations for the differences in the observed haploid induction rates. Some studies have shown a better anthocyanin pigmentation in dent grains (Röber et al., 2005; Milani et al., 2016), while others, in flint grains (Eder \& Chalyk, 2002).

The haploid induction rate is affected by the inducer genotype $\mathrm{x}$ source genotype $\mathrm{x}$ environment (locations, years, or crops) interaction, whose most important factor is the induction ability of the inducer genotype (Eder \& Chalyk, 2002; Röber et al., 2005; Kebede et al., 2011). The efficiency of inducers can be measured by the overall mean of their induction rate for induction crosses in several locations (Prigge et al., 2012b). Therefore, the environment, mainly temperature and humidity, also affects haploid production (Prigge et al., 2012a, 2012b; Milani et al., 2016). For this reason, the rate of haploids produced for each induction cross varies according to environmental changes, which may also include different crops and induction locations (Prigge et al., 2012b; Kebede et al., 2011).

Putative haploids sorted via $R l-n j$ are related to the true induction rate, synonymous with the haploid induction rate (Prigge et al., 2012b; Battistelli et al., 2013; Couto et al., 2015). The production rate of true or putative haploids depends not only on the effects of the inducer, source genotype, and crops, but also on the effects of factors linked to the environment of the induction site, endosperm texture, inbreeding generation, and genetic basis of the source material (Aman \& Sarkar, 1978; Röber et al., 2005; Kebede et al., 2011; Prigge et al., 2012b; Battistelli et al., 2013; Couto et al., 2015). However, these factors are usually evaluated in isolation or only combined in two or three ways, and, many times, the interaction between them cannot be assessed.

The objective of this work was to evaluate the influence of the factors corn genotypes, crop seasons, endosperm texture, genetic background, and genetic basis on putative haploid rates (PHRs) according to the expression of gene Rl-nj.

\section{Materials and Methods}

Forty-one genotypes with different genetic basis (single-cross, double-cross, and triple-cross hybrids; first generation of self-fertilization; and openpollinated populations) were used as the source genotype in induction crosses with the Krasnodar haploid inducer (KHI). The evaluated genotypes were

Pesq. agropec. bras., Brasília, v.55, e01521, 2020

DOI: 10.1590/S1678-3921.pab2020.v55.01521 
obtained from different seed producing companies: DuPont do Brasil S/A (Santa Cruz do Sul, RS, Brazil), Coodetec - Desenvolvimento, Produção e Comercialização Agrícola Ltda. (Cascavel, PR, Brazil), Empresa Brasileira de Pesquisa Agropecuária (Embrapa, Brasília, DF, Brazil), Instituto Agronômico (IAC, Campinas, SP, Brazil), Syngenta Seeds Ltda. (São Paulo, SP, Brazil), Monsanto do Brasil Ltda. (São Paulo, SP, Brazil), Sementes Agroceres S.A. (Uberlândia, MG, Brazil), and Instituto Agronômico do Paraná (Iapar, Londrina, PR, Brazil). The experiment was carried out in two crops: 2013-2014 summer crop (crop 1), from September to February; and 2014 winter crop (crop 2), from February to July. The used materials presented different endosperm textures: dent, semi-dent, flint, semi-flint, sweet, white, and popcorn (Table 1).

Both for the summer and winter crops, the induction crosses were conducted at the experimental farm of Universidade Estadual de Maringá, located in the Iguatemi district, in the state of Paraná, Brazil. The evaluated genotypes were sown in a pollination field composed of two 8-m rows for each material, with a spacing of $0.9 \mathrm{~m}$ between rows and of $0.20 \mathrm{~m}$ between plants, totaling five plants per linear meter. The inducers were sown in an adjacent field, in the proportion of 1.5 inducer rows for each row of source genotype. The inducer genotypes were sown in five different periods, with a one-week interval between sowings: the first and last sowings occurred one week before and 21 days after, respectively, the source genotypes were sown. It is noteworthy that the KHI, used here as a pollen donor, presents a super-early 45-day cycle for flowering and is an open-pollinated variety.

Source genotype ears were protected before the emergence of stigmas. During flowering, pollen was collected in bulk in the inducer field using paper bags, and pollination for haploid induction was performed manually. At maturation, ten ears from each cross were randomly selected, threshed, and dried; seed moisture at harvesting was $16-18 \%$. Seeds were then selected by the expression of the $R 1-n j$ phenotypic marker; the moisture of seeds at this moment was $13-14 \%$. Seeds were then classified as: putative haploids, when they had a purple endosperm and a white embryo (uncolored); and normal, cross-pollinated diploids, when they had a purple endosperm and a purple embryo (Kebede et al., 2011).

The experimental design was completely randomized, with ten replicates (ears). The response variable analyzed was the putative haploid rate (PHR) determined as the proportion of putative haploids, obtained through the $R I-n j$ marker, in relation to the number of diploid seeds. The PHR was assessed using the glm function of the base package of the $\mathrm{R}$ software (R Core Team, 2019). Since the obtained data presented a binomial distribution, referring to a dichotomous response variable (example: putative haploid $=1$ or diploid $=0$ ), the logit link function was used (Melchinger et al., 2016; Dobson \& Barnett, 2018).

The Akaike information criterion (AIC) was applied for the selection of the most appropriate model to explain the effect of the evaluated factors (genotypes, crops, genetic background - companies of origin, endosperm texture, and genetic basis) on the PHR (Snipes \& Taylor, 2014). In this procedure, the best model was the one with the lowest AIC. If more than one model presents the same AIC value, the one that includes the lowest number of explanatory parameters should be chosen. The estimation of the AIC for a certain model is given by: $-2 \mathrm{~L}+2 \mathrm{k}$, where $\mathrm{L}$ is the likelihood function for the model with parameters $\theta$, and $\mathrm{k}$ is the number of parameters (Dobson \& Barnett, 2018). The dispersion data and the result of the type III analysis of variance were also used in decision making; each factor was analyzed separately and did not depend on the order in which the terms were specified in the model.

After the model that best fit the data was found, it was subjected to the residual analysis and other fittingquality criteria. An over dispersion was detected; this occurs when the variability of the residuals is greater than expected by the model. This variability may be the result of heterogeneity among individuals, which was not explained by the covariates, or of a correlation between the observed responses (Turkman \& Silva, 2000). In this case, standard error values and significant differences between contrasts are not properly estimated, moving away from the real value (Hinde \& Demetrio, 1998). For this reason, standard errors were corrected using the quasi-binomial model, in which variance is given by $\mu_{\mathrm{i}}\left(1-\mu_{\mathrm{i}}\right)$, where $\mu$ is the 
mean and is the dispersion parameter, minimizing the effect of overdispersion (Provete et al., 2011).

Table 1. Genetic background (companies of origin), genetic basis, and endosperm textures of the corn (Zea mays) genotypes used for induction crosses in the 2013-2014 summer crop and 2014 winter crop in the municipality of Maringá, in the state of Paraná, Brazil.

\begin{tabular}{|c|c|c|c|}
\hline Companies $^{(1)}$ & $\begin{array}{l}\text { Genetic } \\
\text { basis }^{(2)}\end{array}$ & $\begin{array}{c}\text { Endosperm } \\
\text { texture }\end{array}$ & Genotype \\
\hline Sementes Agroceres S.A. & HD & Semi-dent & AG 1051 \\
\hline Sementes Agroceres S.A. & HS & Flint & AG 8088 \\
\hline Sementes Agroceres S.A. & HS & Semi-dent & AG 8021 \\
\hline Sementes Agroceres S.A. & HS & Semi-flint & AG 7088 \\
\hline Sementes Agroceres S.A. & HS & Semi-flint & AG 9040 \\
\hline Coodetec & $\mathrm{HD}$ & Semi-flint & CD 308 \\
\hline Coodetec & HS & Semi-dent & CD 321 \\
\hline Coodetec & HS & Semi-flint & CD 387 \\
\hline Coodetec & HT & Semi-dent & CD 382 \\
\hline Coodetec & HT & Semi-flint & CD 356 \\
\hline Monsanto do Brasil Ltda. & HS & Semi-dent & DKB $330 Y$ \\
\hline Monsanto do Brasil Ltda. & HS & Semi-flint & DKB 245 \\
\hline Monsanto do Brasil Ltda. & HS & Semi-flint & DKB 390 VT PRO \\
\hline Monsanto do Brasil Ltda. & HT & Semi-flint & DKB 370 \\
\hline Dupont do Brasil & HS & Flint & $30 \mathrm{~B} 39 \mathrm{H}$ \\
\hline Dupont do Brasil & HS & Flint & P4285 \\
\hline Dupont do Brasil & HS & Semi-flint & 30B30 \\
\hline Dupont do Brasil & HS & Semi-flint & $30 \mathrm{~F} 35$ \\
\hline Dupont do Brasil & HS & Semi-flint & $30 \mathrm{~F} 53 \mathrm{H}$ \\
\hline Dupont do Brasil & HS & Semi-flint & P30F36 \\
\hline Dupont do Brasil & HS & Semi-flint & P3431H \\
\hline Dupont do Brasil & HS & Semi-flint & Speed TL \\
\hline Dupont do Brasil & $\mathrm{S} 1$ & Semi-flint & S130F53 \\
\hline Dupont do Brasil & S1 & Semi-flint & S1P2530 \\
\hline Dupont do Brasil & S1 & Semi-flint & S1P3989 \\
\hline Embrapa & HD & White & HD 332 \\
\hline Embrapa & HT & White & HT 932 \\
\hline Embrapa & POP & White & BR 427 \\
\hline Embrapa & POP & Sweet & BR DOCE \\
\hline Embrapa & POP & Sweet & DOCE 2 \\
\hline Embrapa & $\mathrm{S} 1$ & Sweet & S1BR 427 \\
\hline IAC & HS & Popcorn & IAC 112 \\
\hline IAC & POP & Sweet & IAC Doce Cubano \\
\hline Iapar & $\mathrm{HD}$ & White & IPR 119 \\
\hline Syngenta Seeds Ltda. & $\mathrm{HD}$ & Dent & Status \\
\hline Syngenta Seeds Ltda. & $\mathrm{HD}$ & Flint & $30 \mathrm{~F} 80$ \\
\hline Syngenta Seeds Ltda. & HD & Semi-flint & Cargo LT \\
\hline Syngenta Seeds Ltda. & HS & Flint & $30 \mathrm{~K} 64 \mathrm{Y}$ \\
\hline Syngenta Seeds Ltda. & HS & Flint & Formula \\
\hline Syngenta Seeds Ltda. & $\mathrm{S} 1$ & Flint & S1Cargo \\
\hline
\end{tabular}

${ }^{(1)}$ Embrapa, Empresa Brasileira de Pesquisa Agropecuária; IAC, Instituto Agronômico; and Iapar, Instituto Agronômico do Paraná. ${ }^{(2)} \mathrm{HD}$, doublecross hybrid; HS, single-cross hybrid; HT, triple-cross hybrid; S1, first generation of self-fertilization; and POP, open-pollinated population.
An analysis of deviance was conducted according to the selected model, and the interactions of the main factors and nested between the factors were evaluated. The test applied in the analysis of deviance was considered sufficient to classify the differences between crops, which were represented only by two levels. In order to partition crops within the genotype factor, the parameters estimated within the levels of each factor were compared using the t-test for each contrast between means, where the $p$-value was corrected through the false discovery rate (Bretz et al., 2011). The mean rates were later converted into probability through the inverse function of the link function, and corrected rates were obtained.

In addition to the partitioned genotypes within crops, a cluster analysis was performed among the genotypes regarding the estimated induction rates. To this end, the mean Euclidean distance was used to generate a dissimilarity matrix for the genotypes within each crop. The groups of genotypes within each crop were obtained through Ward's hierarchical clustering method, and a dendrogram was generated for each crop (Seidel et al., 2008). The ideal number of clusters was reached based on the D and Hubert indices, using the NbClust package of $\mathrm{R}$ (Charrad et al., 2014). The stability of the generated clusters was evaluated through the bootstrap method, using the cluster boot function of the fpc package of $\mathrm{R}$, in which the adopted algorithm is based on Jaccard's coefficient. The criterion used for group stability was a Jaccard coefficient greater than 0.60 (Hsu, 2015).

\section{Results and Discussions}

The selection of models by the AIC took into account the effects of genotypes, crops, genetic basis, and genetic background - companies of origin on the PHR. The most efficient model to explain the factors involved in the PHR included genotype, crops, and the interaction between them (Table 2).

Considering what was implemented, models 10 , 12 , and 13 were closer to reality than the other tested ones (Table 2). All three models included the effect of genotypes and crop seasons. Model 10 was the simplest, with the lowest number of parameters, including only genotypes, crop seasons, and the interaction between them. One more factor was included in the other two models: endosperm texture in model 12; and genetic 
background - companies of origin in model 13 . However, the type III analysis of variance does not indicate any significance of these main factors, nor of the interactions with crop seasons or nested between factors.

Several authors have reported the effects of crop seasons on induction rates and on the putative haploids classified via $R 1-n j$ expression (Kebede et al., 2011). Differently from Aman \& Sarkar (1978), Röber et al. (2005) identified the effect of locations (Germany, Chile, and Mexico) and years on induction rates. Regarding the efficiency of haploid selection via the $R I-n j$ marker in different environments, these authors found that classification errors were reasonable for dent endosperm sources, but too high for flint endosperms. Röber et al. (2005) and Milani et al. (2016) observed a better anthocyanin pigmentation in dent grains when using the $R 1-n j$ marker to classify seeds from tropical corn genotypes with different textures. Therefore, the type of endosperm can mask the inferred rate of true haploids and positively or negatively influence the PHR (Röber et al., 2005; Milani et al., 2016).

The analysis of deviance for the PHR showed significant effects of genotypes and crop seasons, as well as a significant interaction between these factors.
This is indicative that, for the same genotype in different crop seasons, there were deviations for the PHR when using types I and III analyses of variance (Table 3).

Since the interaction between factors was significant, each factor was partitioned within each level of the other factor, and mean rates were compared by contrasts between the estimated parameters, which were later converted into probability through the inverse function of the link function; corrected rates were then obtained (Table 4 and Figure 1).

Considering the crops partitioned within genotypes, the rates of seeds classified as putative haploids did not differ significantly between crops for most of the source genotypes studied (Table 4). However, for 10 of the 41 genotypes evaluated, the rates obtained between the summer and winter crops were not stable and varied significantly between crops. The observed rates were generally higher for the summer crop season, except for genotype DKB 330Y. The induction cross with BR 427 resulted in the highest variation between crops: $14.69 \%$ for the summer versus $3.80 \%$ for the winter crop season. The highest mean rate, considering both crops, was obtained for the IAC 112 source genotype. In the two crops, the highest rates of $18.21 \%$ for the

Table 2. Summary of the analysis, based on the Akaike information criterion (AIC), of the model generated by the analysis of deviance and type III analysis of variance (ANOVA) to test the influence of corn (Zea mays) genotypes (G), crop seasons $(\mathrm{S})$, endosperm textures $(\mathrm{T})$, genetic background - companies of origin (E), genetic basis (B), and interactions between these factors or nested between them on the putative haploid rates selected via gene R1-navajo.

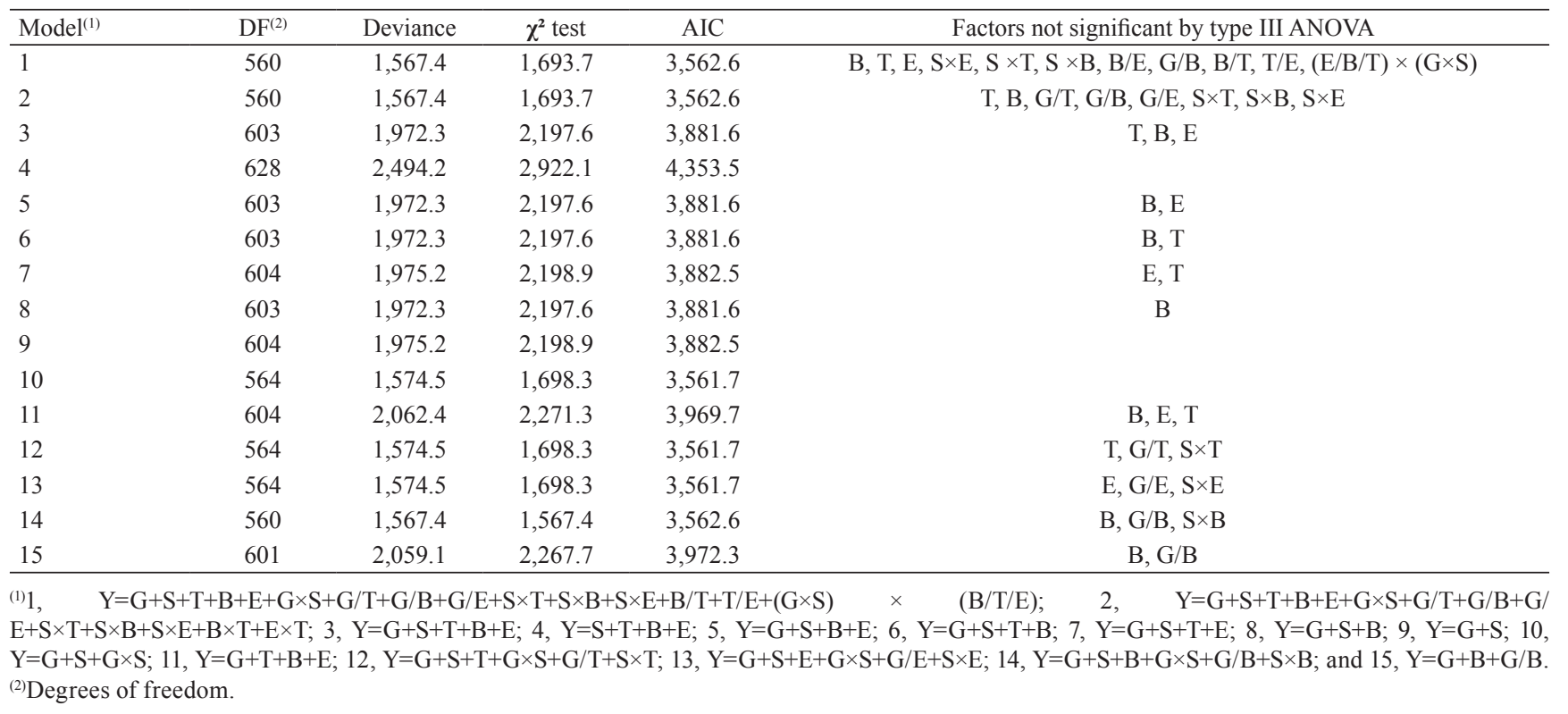

Pesq. agropec. bras., Brasília, v.55, e01521, 2020 DOI: 10.1590/S1678-3921.pab2020.v55.01521 
summer crop and of $26.67 \%$ for the winter crop were found for the induction crosses with genotype IAC 112. The lowest rates of 0.91 and $0.86 \%$ were obtained for induction crosses with genotype AG 7088 in the summer and with genotype CD 308 in the winter, respectively.

For the genotypes partitioned within each crop season level in crops 1 and 2, complex and little conclusive groups were generated by Wald's contrasts. Moreover, a differential behavior of source genotypes regarding the PHR was observed within each crop season. In the summer crop, rates varied more, and two clusters (groups A and B) were formed. Group A included the following source genotypes: 30B30, 30B39H, 30F35, 30F53H, 30F80, AG 7088, AG 8021, AG 8088, AG 9040, Cargo, CD 308, CD 321, CD 356, CD 382, CD 387, IAC Doce Cubano, DKB 245, DKB 330Y, DKB 370, DKB 390 VT PRO, Doce 2, HD 332, HT 392, P30F36, P3431H, P4285, S130F53, and Speed $\mathrm{TL}$; the putative haploid mean was $5.10 \%$. The other genotypes made up group B, with a PRH of $12.29 \%$ (Figure 1 and Table 4).

For crop 2, three clusters (groups A, B, and C) were formed. Group A stood out, especially the crossing with the IAC 112 source genotype, for which the estimated mean rate was $26.67 \%$ putative haploids, the highest for the period (Figure 1). Group B was formed by the induction crosses with genotypes 30B39H, 30F 35, AG 1051, BR Doce, Cargo, DKB 330Y, HT 932, P30F36, S130F53, and S1BR 427, with a mean of $9.38 \%$ selected putative haploids. The other genotypes formed group $\mathrm{C}$, for which the mean of putative haploids was $3.42 \%$ (Table 4).

The overall mean rate of the putative haploids generated in the summer crop (crop 1) was 6.27\%, whereas the general mean rate for the winter crop (crop 2$)$ was $4.74 \%(1 /(1+1 /(\exp (-2.77-0.23)))=0.0474$. Therefore, despite its not too distant average, the winter crop showed a lower performance, which was significant by the analysis of deviance, while the summer crop was more favorable to produce putative haploids. According to the odds ratio estimated for the parameters, induction crosses conducted in the winter crop are less favorable because they generate putative haploids in the proportion of $0.79: 1.0$ in relation to the summer crop, that is, for every 100 haploids generated in the summer crop, 79 are generated in the winter crop season.

Several authors have highlighted differences in the behavior of inducers due to varying environments (locations or crop seasons), the interaction between source genotypes and inducers for the haploid induction rate, and putative haploids (Röber et al., 2005; Prigge et al., 2012b; Battistelli et al., 2013; Couto et al., 2015; Ishii et al., 2016). The effects of the environment and of putative haploids on induction rates is almost a consensus among the works on doubled haploids (Prigge et al., 2012b). Of the edaphoclimatic variables, temperature seems to be the most influential factor when it comes to environmental effects. Pickering \& Morgan (1985), for example, reported the effect of temperature on chromosome elimination in barley (Hordeum vulgare L.), considering this phenomenon as one of the possible contributions of the environment for the formation of haploid seeds.

Environmental effects - represented by crops, years, and locations - on the production of putative haploids may be related to differences in temperature and humidity conditions at the time of the induction crosses. Kebede et al. (2011) detected higher induction rates in the winter of 2008 than in the summer of 2009 at the experimental station of International Maize and Wheat Improvement Center, located in Agua Fria, in the state of Puebla, Mexico. The main difference between the two seasons was a higher temperature during summer (mean average of $26.7^{\circ} \mathrm{C}$, mean

Table 3. Summary of the analysis of deviance of the putative haploid rate identified by the Rl-navajo marker in corn (Zea mays) and obtained from induction crosses between 41 hybrids and the Krasnodar haploid inducer, in the 2013-2014 summer crop season and 2014 winter crop season in the municipality of Maringá, in the state of Paraná, Brazil.

\begin{tabular}{|c|c|c|c|c|c|c|}
\hline \multirow[t]{2}{*}{ Source of variation } & \multirow[t]{2}{*}{ Deviance } & \multirow{2}{*}{$\begin{array}{l}\text { Degree of } \\
\text { freedom }\end{array}$} & \multicolumn{2}{|c|}{ Type I analysis of variance (Anova) } & \multicolumn{2}{|c|}{ Type III analysis of variance (Anova) } \\
\hline & & & $\chi^{2}$ & p-value & $\chi^{2}$ & p-value \\
\hline Intercept & $2,899.6$ & -- & -- & -- & -- & -- \\
\hline Genotypes & $2,060.3$ & 40 & 18.91 & 0.001 & 274.08 & 0.001 \\
\hline Crop seasons & $1,975.2$ & 1 & 312.22 & 0.001 & 34.19 & 0.001 \\
\hline Genotypes x Crops & $1,574.5$ & 40 & 143.56 & 0.001 & 143.56 & 0.001 \\
\hline
\end{tabular}

Pesq. agropec. bras., Brasília, v.55, e01521, 2020

DOI: 10.1590/S1678-3921.pab2020.v55.01521 
minimum of $21.5^{\circ} \mathrm{C}$, and mean maximum of $31.0^{\circ} \mathrm{C}$ ), compared with winter (mean average of $21.5^{\circ} \mathrm{C}$, mean minimum of $16^{\circ} \mathrm{C}$, and mean maximum of $27.7^{\circ} \mathrm{C}$ ). Average rainfall was 798 and $406 \mathrm{~mm}$ for the summer and winter seasons, respectively, and average humidity ranged from 48 to $97 \%$ and from 64 to $99 \%$. However, the highest classification errors were also found in winter, indicating that environmental variables, such

Table 4. Corn (Zea mays) crops partitioned within the genotype factor for the putative haploid rate, and clusters formed within the 2013-2014 summer crop and 2014 winter crop in the municipality of Maringá, in the state of Paraná, Brazil.

\begin{tabular}{|c|c|c|c|c|}
\hline \multirow[t]{3}{*}{ Source genotype } & \multicolumn{2}{|c|}{ Average test (t-test) ${ }^{(1)}$} & \multicolumn{2}{|c|}{ Formed clusters $^{(2)}$} \\
\hline & Crop 1 & Crop 2 & \multirow{2}{*}{$\begin{array}{c}\text { Crop 1 } \\
\text { Rate }(\%)\end{array}$} & \multirow{2}{*}{$\frac{\text { Crop } 2}{\text { Rate (\%) }}$} \\
\hline & & & & \\
\hline 30B30 & $8.25 \mathrm{a}$ & $2.20 \mathrm{~b}$ & $8.25 b$ & $2.2 \mathrm{c}$ \\
\hline 30B39H & $7.18 \mathrm{a}$ & $7.53 \mathrm{a}$ & $7.18 \mathrm{~b}$ & $7.53 b$ \\
\hline $30 \mathrm{~F} 35$ & $5.56 \mathrm{a}$ & $8.37 \mathrm{a}$ & $5.56 \mathrm{~b}$ & $8.37 \mathrm{~b}$ \\
\hline $30 \mathrm{~F} 53 \mathrm{H}$ & $5.48 \mathrm{a}$ & $4.05 \mathrm{a}$ & $5.48 \mathrm{~b}$ & $4.05 c$ \\
\hline $30 \mathrm{~F} 80$ & $4.18 \mathrm{a}$ & $5.21 \mathrm{a}$ & $4.18 \mathrm{~b}$ & $5.21 \mathrm{c}$ \\
\hline $30 \mathrm{~K} 64 \mathrm{Y}$ & $14.67 \mathrm{a}$ & $4.73 b$ & $14.67 \mathrm{a}$ & $4.73 \mathrm{c}$ \\
\hline AG 1051 & $13.23 \mathrm{a}$ & $8.13 \mathrm{a}$ & $13.23 \mathrm{a}$ & $8.13 b$ \\
\hline AG 7088 & $0.91 \mathrm{a}$ & $1.79 \mathrm{a}$ & $0.91 b$ & $1.79 \mathrm{c}$ \\
\hline AG 8021 & $5.80 \mathrm{a}$ & $4.54 \mathrm{a}$ & $5.8 \mathrm{~b}$ & $4.54 \mathrm{c}$ \\
\hline AG 8088 & $3.37 \mathrm{a}$ & $3.16 \mathrm{a}$ & $3.37 \mathrm{~b}$ & $3.16 \mathrm{c}$ \\
\hline AG 9040 & $6.75 \mathrm{a}$ & $2.72 \mathrm{a}$ & $6.75 b$ & $2.72 \mathrm{c}$ \\
\hline BR 427 & $14.69 \mathrm{a}$ & $3.80 \mathrm{~b}$ & $14.69 \mathrm{a}$ & $3.8 \mathrm{c}$ \\
\hline BR Doce & $10.31 \mathrm{a}$ & $9.18 \mathrm{a}$ & $10.31 \mathrm{a}$ & $9.18 \mathrm{~b}$ \\
\hline Cargo & $6.52 \mathrm{a}$ & $9.11 \mathrm{a}$ & $6.52 \mathrm{~b}$ & $9.11 \mathrm{~b}$ \\
\hline CD 308 & $3.72 \mathrm{a}$ & $0.86 \mathrm{a}$ & $3.72 b$ & $0.86 \mathrm{c}$ \\
\hline CD 321 & $3.09 \mathrm{a}$ & $2.50 \mathrm{a}$ & $3.09 \mathrm{~b}$ & $2.5 \mathrm{c}$ \\
\hline CD 356 & $3.63 \mathrm{a}$ & $4.48 \mathrm{a}$ & $3.63 b$ & $4.48 \mathrm{c}$ \\
\hline CD 382 & $4.86 \mathrm{a}$ & $2.67 \mathrm{a}$ & $4.86 b$ & $2.67 \mathrm{c}$ \\
\hline CD 387 & $3.60 \mathrm{a}$ & $6.58 \mathrm{a}$ & $3.6 \mathrm{~b}$ & $6.58 \mathrm{c}$ \\
\hline IAC Doce Cubano & $3.22 \mathrm{a}$ & $5.78 \mathrm{a}$ & $3.22 b$ & $5.78 \mathrm{c}$ \\
\hline DKB 245 & $7.02 \mathrm{a}$ & $4.77 \mathrm{a}$ & $7.02 b$ & $4.77 \mathrm{c}$ \\
\hline DKB 330Y & $7.27 \mathrm{~b}$ & $10.95 \mathrm{a}$ & $7.27 \mathrm{~b}$ & $10.95 b$ \\
\hline DKB 370 & $1.75 \mathrm{a}$ & $4.06 \mathrm{a}$ & $1.75 b$ & $4.06 \mathrm{c}$ \\
\hline DKB 390 VT PRO & $3.32 \mathrm{a}$ & $3.94 \mathrm{a}$ & $3.32 \mathrm{~b}$ & $3.94 \mathrm{c}$ \\
\hline DOCE 2 & $5.37 \mathrm{a}$ & $1.54 \mathrm{a}$ & $5.37 \mathrm{~b}$ & $1.54 \mathrm{c}$ \\
\hline Formula & $10.69 \mathrm{a}$ & $1.45 \mathrm{~b}$ & $10.69 \mathrm{a}$ & $1.45 \mathrm{c}$ \\
\hline HD 332 & $5.18 \mathrm{a}$ & $2.65 \mathrm{a}$ & $5.18 \mathrm{~b}$ & $2.65 \mathrm{c}$ \\
\hline HT 392 & $7.72 \mathrm{a}$ & $5.69 \mathrm{a}$ & $7.72 b$ & $5.69 \mathrm{c}$ \\
\hline HT 932 & $11.96 \mathrm{a}$ & $14.77 \mathrm{a}$ & $11.96 \mathrm{a}$ & $14.77 b$ \\
\hline IAC 112 & $18.21 \mathrm{a}$ & $26.67 \mathrm{a}$ & $18.21 \mathrm{a}$ & $26.67 \mathrm{a}$ \\
\hline IPR 119 & $9.44 \mathrm{a}$ & $3.91 \mathrm{a}$ & $9.44 \mathrm{a}$ & $3.91 \mathrm{c}$ \\
\hline P30F36 & $5.17 \mathrm{a}$ & $7.82 \mathrm{a}$ & $5.17 \mathrm{~b}$ & $7.82 b$ \\
\hline P3431H & $8.51 \mathrm{a}$ & $1.28 \mathrm{~b}$ & $8.51 \mathrm{~b}$ & $1.28 \mathrm{c}$ \\
\hline P4285 & $1.84 \mathrm{a}$ & $1.88 \mathrm{a}$ & $1.84 \mathrm{~b}$ & $1.88 \mathrm{c}$ \\
\hline S130F53 & $5.42 \mathrm{a}$ & $8.61 \mathrm{a}$ & $5.42 \mathrm{~b}$ & $8.61 \mathrm{~b}$ \\
\hline S1BR 427 & $10.35 \mathrm{a}$ & $9.31 \mathrm{a}$ & $10.35 \mathrm{a}$ & $9.31 \mathrm{~b}$ \\
\hline S1Cargo & $10.23 \mathrm{a}$ & $5.40 \mathrm{~b}$ & $10.23 \mathrm{a}$ & $5.4 \mathrm{c}$ \\
\hline $\mathrm{S} 1 \mathrm{P} 2530$ & $13.16 \mathrm{a}$ & $3.08 \mathrm{~b}$ & $13.16 \mathrm{a}$ & $3.08 \mathrm{c}$ \\
\hline S1P3989 & $13.17 \mathrm{a}$ & $3.97 b$ & $13.17 \mathrm{a}$ & $3.97 \mathrm{c}$ \\
\hline Speed TL & $7.99 \mathrm{a}$ & $2.89 \mathrm{a}$ & $7.99 b$ & $2.89 \mathrm{c}$ \\
\hline Status & $9.61 \mathrm{a}$ & $1.19 b$ & $9.61 \mathrm{a}$ & $1.19 \mathrm{c}$ \\
\hline
\end{tabular}

${ }^{(1)}$ Means followed by equal letters, in the lines, do not differ by the t-test, with p-value corrected using the false discovery rate, for contrast between parameters. ${ }^{(2)}$ Means followed by equal letters, in the columns, belong to the same cluster, based on the Euclidean distance and clustering by Ward's method. 
as temperature, may affect anthocyanin pigmentation or haploid generation if they favor chromosome elimination, as described by Pickering \& Morgan (1985).

The observed interactions could be clarified by researches on the magnitude of pigmentation inhibition and chromosome elimination due to environmental factors such as temperature, humidity, and solar radiation, for example. Studies seeking ideal environmental conditions for haploid induction crosses also seem to be necessary, since even the induction rates between ears of the same induction cross may vary (Geiger \& Gordillo, 2009). In addition, an evaluation of the performance of inducers in different locations and crops may indicate ideal regions for nursery installation, the most suitable inducer genotype, and also the best time for induction crosses (Röber et al., 2005).

However, it has not been possible to draw clear conclusions regarding the obtained putative haploid

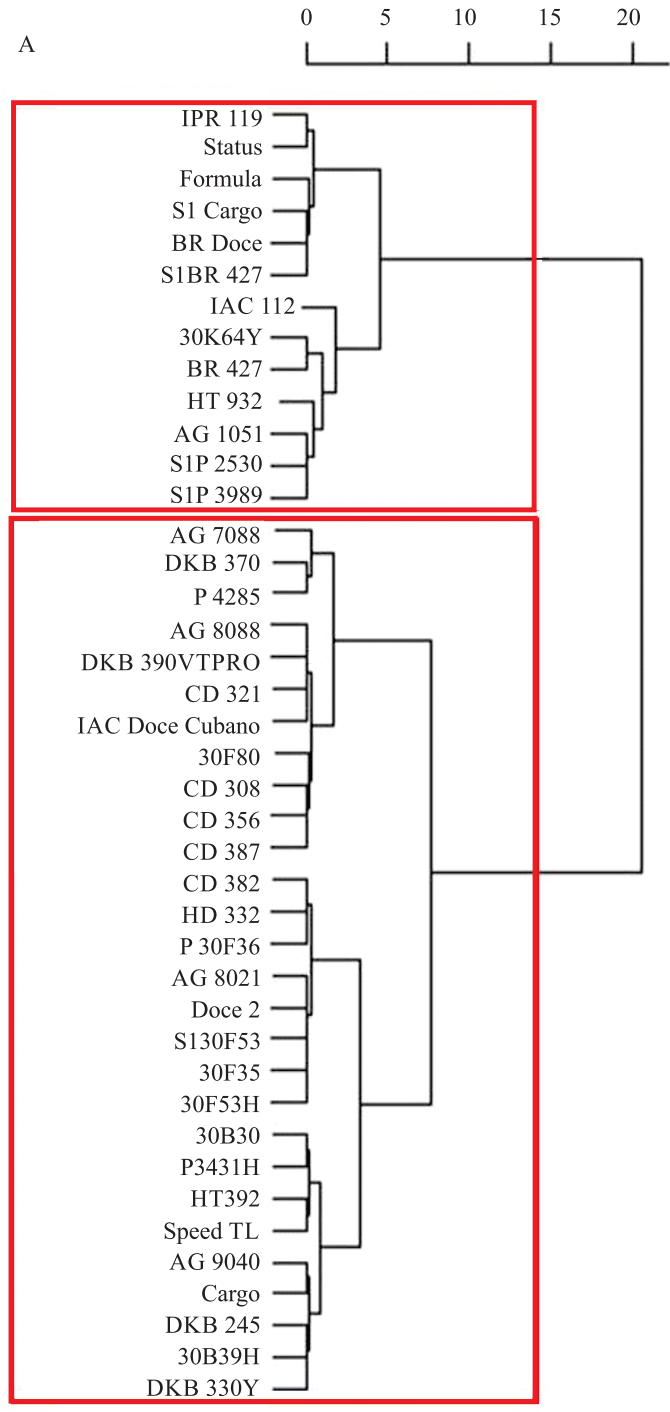

B

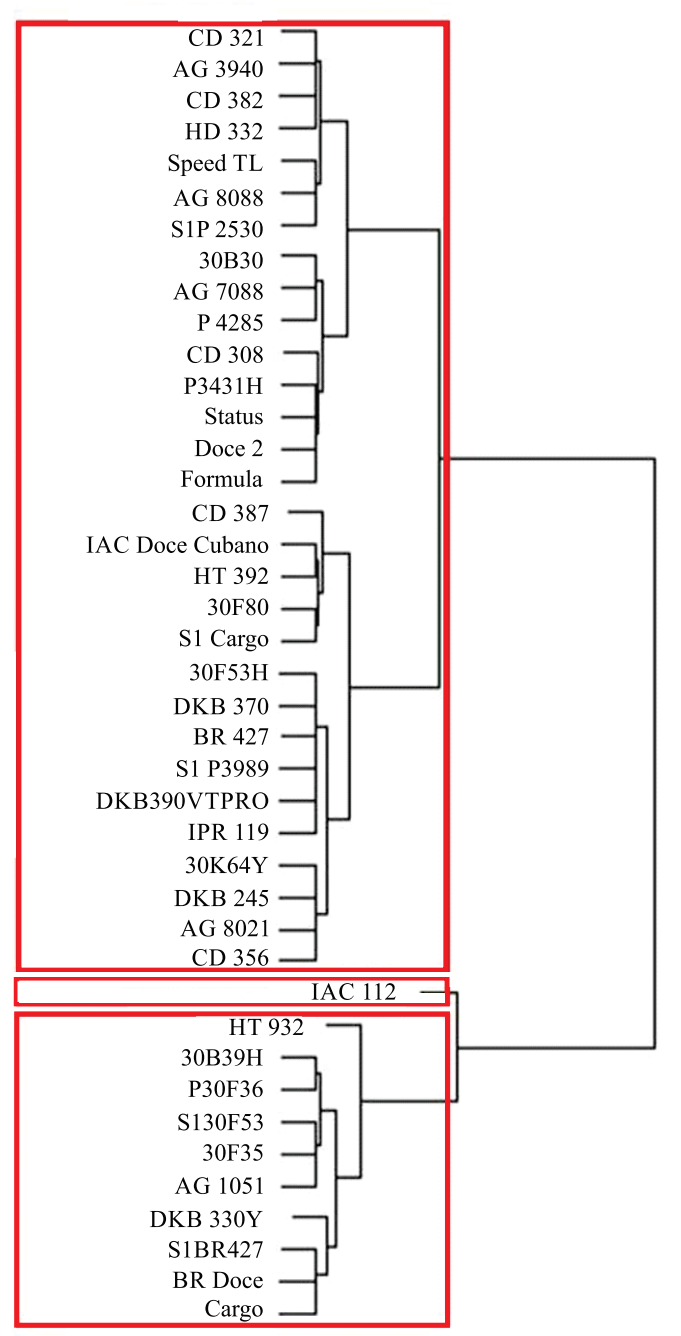

Figure 1. Dendrogram based on the Euclidean distance and clustering by Ward's method for the putative haploid rate obtained for corn (Zea mays) genotypes in: A, the 2013-2014 summer crop season (crop 1); and B, the 2014 winter crop season (crop 2). 
values due to several caveats, showing a low reliability of $R 1-n j$ for haploid classification. Melchinger et al. (2013) reported that the rates obtained with the $R I-n j$ marker differed significantly from those with the gold standard (true condition), exhibiting high rates of false positives (diploids classified as haploids), from 7.8 to $67.6 \%$, and of false negatives (haploids classified as diploids), from 16.3 to $28.6 \%$. In the present study, the overall mean of the putative haploids selected using the phenotypic marker ranged from 7.5 to $22.8 \%$ in crosses combining three different inducers with three source genotypes.

Considering the strong presence of inhibitors of genes of the anthocyanin biosynthetic pathway in seeds of tropical genetic material, the quantification of correct classifications by the marker would be more important than the proportion of putative haploids between crops (Milani et al., 2016), since a low rate of putative haploids can indicate either a lower efficiency in the generation of true haploids or a greater inhibition of anthocyanin expression due to the environment.

Alternatively, another tool for the selection of putative haploids in tropical material is the development of inducers with a high oil content, as proposed by Melchinger et al. (2013) and Wang et al. (2016). However, besides an inducer with high oil levels, a large investment in equipment and automation is also required. Therefore, phenotype markers are still the most used and viable tool for the nondestructive selection of haploids for chromosome doubling.

\section{Conclusions}

1. Corn (Zea mays) crop seasons, genotypes, and the crop seasons $x$ genotypes interaction affect the putative haploid rate.

2. Endosperm texture, genetic basis, and genetic background - companies of origin have no effects on the seed rates classified as putative haploids by the expression of gene R1-navajo.

\section{Acknowledgments}

To Conselho Nacional de Desenvolvimento Científico e Tecnológico ( $\mathrm{CNPq})$, for scholarships granted to the $1^{\text {st }}$ and $8^{\text {th }}$ authors.

\section{References}

AMAN, M.A.; SARKAR, K.R. Selection for haploidy inducing potential in maize. Indian Journal of Genetics and Plant Breeding, v.38, p.452-457, 1978.

BATTISTELLI, G.M.; VON PINHO, R.G.; JUSTUS, A.; COUTO, E.G.O.; BALESTRE, M. Production and identification of doubled haploids in tropical maize. Genetics and Molecular Research, v.12, p.4230-4242, 2013. DOI: https://doi.org/10.4238/2013. October.7.9.

BRETZ, F.; HOTHORN, T.; WESTFAlL, P. Multiple comparisons using R. Boca Raton: Chapman \& Hall/CRC, 2011. $182 \mathrm{p}$.

CHAIKAM, V.; MOLENAAR, W.; MELCHINGER, A.E.; BODDUPALLI, P.M. Doubled haploid technology for line development in maize: technical advances and prospects. Theoretical and Applied Genetics, v.132, p.3227-3243, 2019. DOI: https://doi.org/10.1007/s00122-019-03433-x.

CHAIKAM, V.; NAIR, S.K.; BABU, R.; MARTINEZ, L.; TEJOMURTULA, J.; BODDUPALLI, P.M. Analysis of effectiveness of $R 1-n j$ anthocyanin marker for in vivo haploid identification in maize and molecular markers for predicting the inhibition of R1-nj expression. Theoretical and Applied Genetics, v.128, p.159-171, 2015. DOI: https://doi.org/10.1007/ s00122-014-2419-3.

CHARRAD, M.; GHAZZALI, N.; BOITEAU, V.; NIKNAFS, A. NbClust: an $\mathrm{R}$ package for determining the relevant number of clusters in a data set. Journal of Statistical Software, v.61, p.136, 2014. DOI: https://doi.org/10.18637/jss.v061.i06.

COE, E.H. Anthocyanin genetics. In: FREELING, M.; WALBOT, V. (Eds.). The maize handbook. New York: Springer-Verlag, 1994. p.279-281. DOI: https://doi.org/10.1007/978-1-4612-2694-9_34.

COUTO, E.G. de O.; VON PINHO, E.V. de R.; VON PINHO, R.G.; VEIGA, A.D.; BUSTAMANTE, F. de O.; DIAS, K.O. das $\mathrm{G}$. In vivo haploid induction and efficiency of two chromosome duplication protocols in tropical maize. Ciência e Agrotecnologia, v.39, p.435-442, 2015. DOI: https://doi.org/10.1590/S141370542015000500002 .

DOBSON, A.J.; BARNETT, A.G. An introduction to generalized linear models. $4^{\text {th }}$ ed. Boca Raton: CRC Press, 2018. 376p.

EDER, J.; CHALYK, S. In vivo haploid induction in maize. Theoretical and Applied Genetics, v.104, p.703-708, 2002. DOI: https://doi.org/10.1007/s00122-001-0773-4.

GEIGER, H.H.; GORDILLO, G.A. Doubled haploids in hybrid maize breeding. Maydica, v.54, p.485-499, 2009.

HINDE, J.; DEMÉTRIO, C.G.B. Overdispersion: model and estimation. Computational Statistics \& Data Analysis, v.27, p.151-170, 1998. DOI: https://doi.org/10.1016/S01679473(98)00007-3.

HSU, D. Comparison of integrated clustering methods for accurate and stable prediction of building energy consumption data. Applied Energy, v.160, p.153-163, 2015. DOI. https://doi.org/10.1016/j.apenergy.2015.08.126. 
ISHII, T.; KARIMI-ASHTIYANI, R.;HOUBEN, A.Haploidization via chromosome elimination: means and mechanisms. Annual Review of Plant Biology, v.67, p.421-438. 2016, DOI: https://doi.org/10.1146/annurev-arplant-043014-114714.

KEBEDE, A.Z.; DHILLON, B.S.; SCHIPPRACK, W.; ARAUS, J.L.; BÄNZIGER, M.; SEMAGN, K.; ALVARADO, G.; MELCHINGER, A.E. Effect of source germplasm and season on the in vivo haploid induction rate in tropical maize. Euphytica, v.180, p.219-226, 2011. DOI: https://doi.org/10.1007/s10681-0110376-3.

MELCHINGER, A.E.; MOLENAAR, W.S.; MIRDITA, V.; SCHIPPRACK, W. Colchicine alternatives for chromosome doubling in maize haploids for doubled-haploid production. Crop Science, v.56, p.559-569, 2016. DOI: https://doi.org/10.2135/ cropsci2015.06.0383.

MELCHINGER, A.E.; SCHIPPRACK, W.; WÜRSCHUM, T.; CHEN, S.; TECHNOW, F. Rapid and accurate identification of in vivo-induced haploid seeds based on oil content in maize. Scientific Reports, v.3, art.2129, 2013. DOI: https://oi.org/10.1038/srep02129.

MILANI, K.F.; BALERONI, A.G.; SILVA, H.A.; MENDESBONATO, A.B.; PINTO, R.J.B.; SCAPIM, C.A. Effectiveness of the R1-navajo embryo marker on sorting haploids in tropical maize germplasm. Maydica, v.61, p.1-8, 2016.

NANDA, D.K.; CHASE, S.S. An embryo marker for detecting monoploids of maize (Zea mays L.). Crop Science, v.6, p.213-215, 1966. DOI: https://doi.org/10.2135/ cropsci1966.0011183X000600020036x.

PICKERING, R.A.; MORGAN, P.W. The influence of temperature on chromosome elimination during embryo development in crosses involving Hordeum spp., wheat (Triticum aestivum L.) and rye (Secale cereale L.). Theoretical and Applied Genetics, v.70, p.199-206, 1985. DOI: https://doi.org/10.1007/BF00275322.

PRIGGE, V.; SCHIPPRACK, W.; MAHUKU, G.; ATLIN, G.N.; MELCHINGER, A.E. Development of in vivo haploid inducers for tropical maize breeding programs. Euphytica, v.185, p.481490, 2012a. DOI: https://doi.org/10.1007/s10681-012-0657-5.
PRIGGE, V.; XU, X.; LI, L.; BABU, R.; CHEN, S.; ATLIN, G.N.; MELCHINGER, A.E. New insights into the genetics of in vivo induction of maternal haploids, the backbone of doubled haploid technology in maize. Genetics, v.190, p.781-793, 2012b. DOI: https://doi.org/10.1534/genetics.111.133066.

PROVETE, D.B.; SILVA, F.R. da; SOUZA, T.G. Estatística aplicada à ecologia usando o R. São Jose do Rio Preto: Unesp, 2011. 211p.

R CORE TEAM. R: a language and environment for statistical computing. Vienna: R Foundation for Statistical Computing, 2019. Available at: $<$ https://www.R-project.org $>$. Accessed on: Dec. 42020.

RIBEIRO, C.B.; PEREIRA, F. de C.; NÓBREGA FILHO, L. da; REZENDE, B.A.; DIAS, K.O. das G.; BRAZ, G.T.; RUY, M.C.; SILVA, M.B.; CENZI, G.; TECHIO, V.H.; SOUZA, J.C. de. Haploid identification using tropicalized haploid inducer progenies in maize. Crop Breeding and Applied Biotechnology, v.18, p.1623, 2018. DOI: https://doi.org/10.1590/1984-70332018v18n1a3.

RÖBER, F.K.; GORDILLO, G.A.; GEIGER, H.H. In vivo haploid induction in maize - performance of new inducers and significance of doubled haploid lines in hybrid breeding. Maydica, v.50, p.275$283,2005$.

SEIDEL, E.J.; MOREIRA JÚNIOR, F. de J.; ANSUJ, A.P.; NOAL, M.R.C. Comparação entre o método Ward e o método K-médias no agrupamento de produtores de leite. Ciência e Natura, v.30, p.7-15, 2008. DOI: https://doi.org/10.5902/2179460X9737.

SNIPES, M.; TAYLOR, D.C. Model selection and Akaike information criteria: an example from wine ratings and prices. Wine Economics and Policy, v.3, p.3-9, 2014. DOI: https://doi.org/10.1016/j.wep.2014.03.001.

TURKMAN, A.M.A; SILVA, G.L. Modelos Lineares Generalizados - da teoria à pratica. Portugal: Sociedade Portuguesa de Estatística, 2000. 151p.

WANG, H.; LIU, J.; XU, X.; HUANG, Q.; CHEN, S.; YANG, P.; CHEN, S.; SONG, Y. Fully-automated high-throughput NMR system for screening of haploid kernels of maize (corn) by measurement of oil content. PLoS ONE, v.11, e0159444, 2016. DOI: https://doi.org/10.1371/journal.pone.0159444. 